\title{
Preparation of pedagogical university students for the organization of upbringing practices
}

\section{Preparação de estudantes universitários pedagógicos para a organização de práticas de educação}

\section{Preparación de los estudiantes universitarios de pedagogía para la organización de las prácticas de crianza}

\author{
Svetlana Nikolaevna Gorshenina ${ }^{1}$ iD, Irina Borisovna Buyanova1 ${ }^{\text {iD }}$, \\ Irina Alexandrovna Neyasova ${ }^{1}$ (D), Larisa Alexandrovna Serikova1 ${ }^{1}$, \\ Tatiana Ivanovna Shukshina ${ }^{1}$ (D)
}

${ }^{1}$ Mordovian State Pedagogical University named after M.E. Evseviev, Saransk, Russia.

Corresponding author:

Svetlana Nikolaevna Gorshenina

Email: sngorshenina@yandex.ru

How to cite: Gorshenina, S. N., Buyanova, I. B., Neyasova, I. A., Serikova, L. A., \& Shukshina, T. I. (2022). Preparation of pedagogical university students for the organization of upbringing practices. Revista Tempos e Espaços em Educação, 14(33), e17221. http://dx.doi.org/10.20952/revtee.v14i33.17221

\begin{abstract}
The purpose of the paper is to test a model of practice-oriented training of pedagogical university students for the organization of upbringing practices. The study uses the methods of the theoretical (literature analysis, comparison, generalization, modeling) and empirical (pedagogical experiment, praximetric methods) levels and statistical processing of experimental data. The study is carried out in three stages. At the first stage, the state of the problem of practice-oriented training of teachers for upbringing work in pedagogical theory and practice is analyzed and a model of practice-oriented training of pedagogical university students for the organization of upbringing practices is developed. The second stage involves experimental approbation of the developed model. At the third stage, the obtained results are systematized, generalized, processed, and reported. The results of the study dive evidence of an increase in the level of pedagogical university students' readiness for the organization of upbringing practices. The materials of the paper can be useful for scholars and teachers in educational organizations.
\end{abstract}

Keywords: Professional training. Upbringing. Upbringing practices. Pedagogical university student. Readiness to organize upbringing practices. 


\section{RESUMO}

O objectivo do documento é testar um modelo de formação orientada para a prática dos estudantes universitários pedagógicos para a organização de práticas de educação. O estudo utiliza os métodos dos níveis teórico (análise bibliográfica, comparação, generalização, modelação) e empírico (experiência pedagógica, métodos praximétricos) e processamento estatístico de dados experimentais. $\mathrm{O}$ estudo é levado a cabo em três fases. Na primeira fase, é analisado o estado do problema da formação orientada para a prática de professores para o trabalho de educação em teoria e prática pedagógica e é desenvolvido um modelo de formação orientada para a prática de estudantes universitários pedagógicos para a organização de práticas de educação. A segunda fase envolve a aprovação experimental do modelo desenvolvido. Na terceira fase, os resultados obtidos são sistematizados, generalizados, processados, e reportados. Os resultados do estudo revelam um aumento do nível de prontidão dos estudantes universitários pedagógicos para a organização de práticas de educação. Os materiais do estudo podem ser úteis para estudiosos e professores em organizações educacionais.

Palavras-chave: Formação profissional. Formação profissional. Práticas de educação. Estudante universitário pedagógico. Prontidão para organizar práticas de educação.

\section{RESUMEN}

El propósito del trabajo es probar un modelo de formación orientada a la práctica de los estudiantes universitarios de pedagogía para la organización de las prácticas de crianza. El estudio utiliza los métodos de los niveles teórico (análisis de la literatura, comparación, generalización, modelización) y empírico (experimento pedagógico, métodos praximétricos) y el tratamiento estadístico de los datos experimentales. El estudio se lleva a cabo en tres etapas. En la primera etapa, se analiza el estado del problema de la formación orientada a la práctica de los profesores para el trabajo de crianza en la teoría y la práctica pedagógica y se desarrolla un modelo de formación orientada a la práctica de los estudiantes universitarios de pedagogía para la organización de las prácticas de crianza. La segunda etapa consiste en la aprobación experimental del modelo desarrollado. En la tercera etapa se sistematizan, generalizan, procesan y comunican los resultados obtenidos. Los resultados del estudio evidencian el aumento del nivel de preparación de los estudiantes universitarios de pedagogía para la organización de las prácticas de crianza. Los materiales del trabajo pueden ser útiles para los académicos y profesores de las organizaciones educativas.

Palabras clave: Formación profesional. Crianza. Prácticas de crianza. Estudiante universitario de pedagogía. Disposición para organizar las prácticas de crianza.

\section{INTRODUCTION}

In modern conditions, raising a person able to achieve considerable success in life in the context of the renewing social situation and ready for personal and professional development and moral and physical self-improvement is becoming a factor of decisive importance. The priority task of the upbringing of children and youth is established at the state level, amendments are made to legislation to reinforce and revitalize the upbringing component of the Russian education system.

In the present socio-cultural situation, the new generation is viewed as a subject of social life. Proceeding from this, the process of upbringing is interpreted as the organization of a "live situation" of interaction with children (Demakova \& Shustova, 2018) that provides for their assimilation of universal human values, the achievements of human culture, and life meanings, the development of their viewpoints and convictions, as well as the identification of personal resources for self-identification and self-development. In recent studies (Fiofanova, 2012; Milovanova \& Faizullina, 2021; Selivanova et al., 2020), the value-meaning interaction of teachers and students and the organization of the life of children and youth aimed at the formation of their socio-cultural experience and subjective position is defined through the implementation of upbringing practices. 
Critical importance in the organization of upbringing practices is attributed to the realization of the co-existence approach, which is based "on the value-meaning interaction between the teacher and students, on the equality, openness, and mutual trust of the participants in communication, the common experience and comprehension of the situation of interaction" (Shustova, 2021, p. 7). The indicated interaction of the subjects of educational relations by means of activities as part of the organization of upbringing practices calls for a reconsideration of the approaches to training pedagogical personnel and a renewal of the content and process aspects of this training to allow for the mastery of professional competencies in the upbringing of the new generation. The measure most fitting for the solution of this problem is the development of a model of practice-oriented training of pedagogical university students for the organization of upbringing practices.

\section{LITERATURE REVIEW}

Resolution of the problem of training teachers for upbringing work is not a novel topic in scientific literature. Foreign and Russian research discloses the theoretical and methodical, organizational and process, and content aspects of practice-oriented teacher training, including the formation of teachers' readiness for upbringing activities.

\begin{tabular}{|c|c|}
\hline Issue under study & Source \\
\hline $\begin{array}{l}\text { Content and technology of practical training of } \\
\text { teachers }\end{array}$ & $\begin{array}{l}\text { P. Goodyear, G. Salmon, M. Spector, C. Steeples, S. Tickner } \\
\text { (2001), G. Petty (2006), K.M. Zeichner, H.G. Conklin (2005) }\end{array}$ \\
\hline Assessment of teachers' professional competencies & $\begin{array}{l}\text { P. Black, C. Harrison, C. Lee, B. Marshall, D. William (2003), } \\
\text { M. Ilanlou, M. Zand (2011), W. Robinson (2006), A.J. Wayne, } \\
\text { P. Youngs (2004) }\end{array}$ \\
\hline rocess of training & $\begin{array}{l}\text { L.V. Baiborodova, M.V. Gruzdev, I.G. Kharisova (2018), S.N. } \\
\text { Gorshenina, I.B. Buianova, I.A. Neiasova, L.A. Serikova (2020) }\end{array}$ \\
\hline $\begin{array}{l}\text { Conditions and technologies for the effectiveness of } \\
\text { training class teachers for the upbringing interaction } \\
\text { with students }\end{array}$ & $\begin{array}{l}\text { T.A. Belova, Y.V. Vardanyan, R.D. Chumanina, } \\
\text { N.P. Kondratyeva, O.V. Kudashkina, T.V. Savinova (2018), } \\
\text { N.F. Belyaeva, M.S. Volkova, V.V. Miroshkin, E.V. Shepeleva, } \\
\text { M.G. Yakuncheva (2018), S.N. Gorshenina, I.A. Neiasova } \\
\text { (2018) }\end{array}$ \\
\hline curricular & $\begin{array}{l}\text { M.Yu. Kulebyakina, T.A. Ivanova, L.S. Kapkaeva, } \\
\text { N.N. Derbedeneva, V.M. Pronkina (2018), S.V. Kutnyak, } \\
\text { D.V. Kizhaeva, E.V. Dementieva, A.E. Falileev (2019) }\end{array}$ \\
\hline $\begin{array}{l}\text { Tra } \\
\text { the }\end{array}$ & $\begin{array}{l}\text { I.B. Buyanova, S.N. Gorshenina, I.A. Neyasova, L.A. Serikova, } \\
\text { T. I. Shukshina (2020) }\end{array}$ \\
\hline $\begin{array}{l}\text { Design and implementation of upbringing programs } \\
\text { in educational organizations }\end{array}$ & $\begin{array}{l}\text { O.V. Kurteeva (2021), O.A. Chikova, I.S. Shakhnovich, I.A. } \\
\text { Popp (2021) }\end{array}$ \\
\hline
\end{tabular}

However, in Russian higher education practice, the problem of preparing students for the organization of upbringing practices is not explored in full, the factors and mechanisms of this process are not disclosed, which raises the need for an active search for modern approaches to the indicated problem.

\section{METHODS}

Analysis of literature on the problem under examination allows determining the methodological foundation for the present study, which is formed by the competency, activity, and personality-oriented approaches.

The competency approach determines the logic behind the analysis of the sphere of professional activity of pedagogical university students, the choice of competencies in the context of the main program of vocational education characterizing students' readiness for upbringing work, and the selection of the content of education ensuring the compliance of the mastered 
competencies with the requirements of the federal state educational standard for higher education and the professional standard for teachers.

Adoption of the ideas of the activity approach implies putting the students into the position of an active subject of learning and mastery of work activities by organizing various types of activities and allows to shift the focus from the teacher and the content of the educational program to the expected educational results.

The personality-oriented approach allows appealing to the practical socio-pedagogical and personal experience of students in the educational, extracurricular, and socially significant activities, as well as to individualize the process of mastering upbringing practices.

The study is based on the use of theoretical methods, the priority among which are literature analysis, comparison, systematization of materials on practice-oriented teacher training, prognosis, and modeling. The deployed empirical methods include pedagogical experiment, praximetric methods, expert assessment, and author's control and assessment materials for evaluating students' professional competencies (case-assessments, professional and situational tasks, creative and design assignments). The control stage of the experiment employs a mathematical statistics method (Pearson's chi-squared test).

The experiment is conducted during the 2020-2021 academic year. The experimental base of the study is the Mordovian State Pedagogical University named after M.E. Evseviev. The experiment sample includes 140 2nd-year students in the direction of training "Pedagogical education".

The experimental study is conducted in stages. The first stage involves the analysis of the current state of the problem of practice-oriented training of teachers for upbringing activities in pedagogical theory and practice and the development of the program and criterion-diagnostic instruments for assessing the readiness of pedagogical university students for organizing upbringing practices. The diagnostic instruments used include the "Motivation of professional activity" method (Rean, 2002), a test assessing the level of formation of projective pedagogical skills (Shumeiko, 2017), a diagnostic technique for the individual degree of reflexivity according to A.V. Karpov (Orlova, 2006), a questionnaire for the assessment of the priority of research on pedagogical problems (Andreev, 2013), case-assessments, the author's questionnaire determining readiness for the organization of upbringing practices, professional and situational tasks, and creative and design tasks. The control (CG) and experimental (EG-1, EG-2, EG-3, EG-4) groups are formed for the experiment.

At the second stage, experimental approbation of the model of practice-oriented training of pedagogical university students for the organization of upbringing practices is conducted along with an independent assessment of said readiness in the students. In the experimental groups, the model is adopted in full, while in the control group, only some elements of the model are put into practice.

The third stage involves the systematization, summarization, processing, and reporting of the obtained results, the conditions for effective practice-oriented training of pedagogical university students for the organization of upbringing practices are identified.

\section{RESULTS AND DISCUSSION}

\section{Description of the Model}

An opportunity for a holistic perception of the structure of the studied process, as well as for identification of the logic of training pedagogical university students for organizing upbringing practices is provided by a structural-functional model, which integrates the interrelated components of the purpose, content, process and technology, and diagnostics and results.

The purpose component of the model serves the orientation and goal-setting function, reflects the social demand for the training of pedagogical university students for the organization 
of upbringing practices represented in regulatory documents (professional standard "Teacher", the Federal State Educational Standard of Higher Education for the direction of training "Pedagogical education" (Bachelor's degree)), and supports the identification of the goal and objectives of the model. The goal of the model lies in the formation of readiness for organizing upbringing practices in pedagogical university students. Said readiness is interpreted as an integral professional and personal quality characterized by the presence of an attitude to conducting upbringing activities, a set of knowledge about the theoretical and procedural foundations of upbringing practices, as well as the methods and methods of work for the implementation of upbringing practices in professional work accounting for the age and psychological characteristics of students.

The content component of the model discloses the substantial core of the formation of students' readiness for organizing upbringing practices in the context of professional training. This component includes two blocks - the theoretical and the practical. The two blocks are distinguished based on the culturological conception of the content of education (Kraevskii \& Lerner, 1983), which presupposes that the source for the content of education is the socio-cultural experience formed from the knowledge about the world and methods of activity, the experience of practicing these methods of activity (skills), the experience of creative activity, and the experience of the emotional and value attitude to the world. In relying on this conception, we take into consideration the possibilities of its transformation in the process of the formation of readiness for the organization of upbringing practices in pedagogical university students.

The theoretical block of the content component of the model presupposes that students acquire the knowledge necessary to effectively implement the educational process: the concepts, theories, and fundamental principles of education; the essence of the organization of the upbringing process; the modern models of upbringing; the content, forms, methods, and technologies of upbringing; the essence and procedural characteristics of upbringing practices (goal-setting practices in upbringing, the practices of designing upbringing activities, diagnostic practices of assessing the effectiveness of upbringing work); the peculiarities of organizing upbringing practices in the context of the digitalization of the educational process; the specific features of organizing upbringing practices for students at various stages of age development; the methods of assessing the effectiveness of upbringing practice organization. This aspect of training is met by means of the basic academic disciplines of the main vocational education program as part of the "Psychological and pedagogical" module ("Psychology", "Pedagogy") and the "Upbringing activity" module ("Technology and organization of upbringing practices," "Psychology of upbringing practices," "Fundamentals of camp counselor work").

The practical block of the content component of the model focuses on students' mastery of skills and abilities necessary for the organization and implementation of upbringing practices:

- the ability to set goals, determine the optimal forms, methods, means, and technologies for the organization of upbringing practices;

- the skills of modeling, designing, and organizing upbringing practices;

- the diagnostic skills of assessing the initial level of students' upbringing;

- the ability to develop the program and methodical support for upbringing practices;

- the ability to account for the individual psychological characteristics of students in organizing upbringing practices and establish subject-subject interaction with students;

- the ability to implement the co-existence principle in organizing upbringing practices and child-adult communities;

- the ability to use the resources and opportunities of the educational environment in organizing upbringing practices;

- the skills of analyzing and reflecting on the results of one's work and the work of students in the process of the implementation of upbringing practices.

The practical training of pedagogical university students for the organization of upbringing 
practices is carried out in the process of:

- studying in lessons, by means of professional, situational, and case tasks, competencyoriented assignments, the design of upbringing events, author's upbringing programs, and upbringing practices;

- quasi-professional and educational-professional activities in the basic departments of the university through professional probations (the "Pedagogical Descent" project, the "Art of Upbringing" case championship, the "What Would X Do?" problem-solving role-play, the "Island of Love, Kindness, and Understanding" educational web quest, the "Modern Technologies of Tutoring Upbringing Practices: Designing an Individual Educational Trajectory" project);

- professionally-oriented activities (industrial (pedagogical) practice, industrial (pedagogical) practice (camp counseling internship));

- extracurricular, upbringing, and socio-cultural activities aimed at improving the social activity of students (meetings of the educational club "Creative pedagogy: new educational practices," the social project "100 questions to the teacher (class teacher, counselor)," sociallyoriented game "Upbringing Monopoly," intellectual quiz "Educational quiz," project "Pedagogical Lecture Series," project "Film Enlightenment," social and educational project "Give Good");

- research and project activities (the contest of research and creative works "Remembering the Teacher", the contest of authors' methodological developments in upbringing educational interaction "Raising a New Generation", the contest of research and project works "Youth Initiatives in Upbringing", the contest of methodological developments "Digital Tools for Organizing Upbringing Practices");

- the study advanced experience and innovative educational practices as part of the activities of the university's Center for Spiritual and Moral Culture and Upbringing (the project "Visiting the master", meetings and dialogues with representatives of the clergy, Open Space for the development of the historical and cultural heritage of the region, brainstorming "Raising Generation Z", foresight session "Fundamental values of spiritual and moral upbringing: problems and advice to parents".

The process and technology component of the model reflects the forms, methods, and technologies of professional training in their dialectic unity and defines four steps of pedagogical university students' practice-oriented training for the organization of upbringing practices (the vocational guidance stage, the professional adaptation stage, the professional technology stage, and the results and assessment stage).

The diagnostics and results component of the model contains the methods of assessing the ongoing results, as well as the criterion-level characteristic of students' readiness for the organization of upbringing practices. The identified criteria of readiness for the organization of upbringing practices in pedagogical university students are the motivational-value criterion, the cognitive criterion, and the activity-reflection criterion.

The motivational-value criterion covers the characteristics of a future teacher's personality defined by their value attitudes: values, orientation towards communication and interaction, the presence of qualities that shape the position of an active subject in the educational process. The motivation of teacher students defines the depth of their recognition of the humanistic value of upbringing practices, their striving for a guaranteed result of upbringing work through the organization of various upbringing practices. This component of future teachers' readiness for organizing upbringing practices characterizes their professional orientation, the personal professionally important qualities that contribute to a positive influence on the development of learners' personalities.

The cognitive criterion of readiness for organizing educational practices is characterized by the availability of knowledge necessary for the effective realization of the educational process, in particular, knowledge of the normative legal documents regulating educational activities, the 
concepts and theories of upbringing, the fundamental principles of upbringing, and the essence and procedural characteristics of upbringing practices.

The activity-reflection criterion is associated with the formation of practical readiness for the organization of upbringing practices for the development of students' personalities. This criterion reflects the operational characteristics, the ability to use the methods, practices, and techniques of upbringing activities, the ability to carry out self-reflection and self-assessment of the implementation of upbringing practices with subsequent correction.

In accordance with the aforementioned criteria, we identify the advanced, baseline, and threshold levels of pedagogical university students' readiness for the organization of upbringing practices.

\section{Experimental Data}

Analysis of the results of the ascertaining stage of the experiment shows that the level of students' readiness for the organization of upbringing practices is similar by all of the identified criteria (the motivational-value, the cognitive, and the activity-reflection). Analysis of the levels of students' readiness for organizing upbringing practices allows determining the threshold level in both the experimental groups and the control group - 84\% (EG-1), 84.0\% (EG-1), 78.3\% (EG-2), 73.1\% (EG-3), 88.5\% (EG-4), 65.0\% (CG). This ensures that the experimental conditions are uniform.

At the control stage, comparative analysis of the study results allows detecting the overall dynamics of averaged indicators of students' levels of preparedness for the organization of upbringing practices relative to the start of the experiment (SE) and its end (EE) (Table 1).

Table 1. Average indicators of the level of readiness of pedagogical university students to organize upbringing practices $(\mathrm{n} / \%)$.

\begin{tabular}{|c|c|c|c|c|c|c|c|c|c|c|}
\hline \multirow[t]{2}{*}{ Level } & \multicolumn{2}{|l|}{ EG-1 } & \multicolumn{2}{|l|}{ EG-2 } & \multicolumn{2}{|l|}{ EG-3 } & \multicolumn{2}{|l|}{ EG-4 } & \multicolumn{2}{|l|}{ CG } \\
\hline & SE & $\mathrm{EE}$ & SE & $\mathrm{EE}$ & SE & $\mathrm{EE}$ & SE & $\mathrm{EE}$ & SE & $\mathrm{EE}$ \\
\hline advanced & $1 / 4.0$ & $5 / 20.0$ & $0 / 0$ & $6 / 26.0$ & $1 / 3.8$ & $5 / 19.2$ & $0 / 0$ & $3 / 11.5$ & $1 / 5.0$ & $1 / 5.0$ \\
\hline baseline & $3 / 12.0$ & $\begin{array}{l}13 / 52 \\
0\end{array}$ & $5 / 21.7$ & $\begin{array}{l}11 / 48 . \\
0\end{array}$ & $6 / 23.1$ & $\begin{array}{l}15 / 57 \\
7\end{array}$ & $3 / 11.5$ & $\begin{array}{l}10 / 38 \\
5\end{array}$ & $6 / 30.0$ & $7 / 35.0$ \\
\hline threshold & $21 / 84.0$ & $7 / 28.0$ & $18 / 78.3$ & $6 / 26.0$ & $19 / 73.1$ & $6 / 23.1$ & $23 / 88.5$ & $\begin{array}{l}13 / \\
50.0\end{array}$ & $13 / 65.0$ & $12 / 60.0$ \\
\hline
\end{tabular}

The data in the table indicate the predominance of the baseline level of students' readiness for the organization of upbringing practices in the experimental groups, followed by the advanced level (21.8\%), the smaller group is the threshold level (20.5\%). The control group predominantly demonstrates the threshold level of readiness for organizing upbringing activities (55.1\%) followed by the baseline level (37.3\%), while the advanced level is expressed insufficiently (7.6\%). Thus, analysis of the research data reveals an increase in the readiness to organize upbringing practices in pedagogical university students.

The reliability of the obtained results is tested using Pearson's chi-squared test. Since $\chi^{2}$ emp $=7.85>\chi^{2} 0.05=6.97$, the reliability of differences between the experimental and control groups is $95 \%$. The pattern detected at the control stage allows establishing that the experimental groups demonstrate a higher level of readiness for the organization of upbringing practices compared to the control group, which testifies to the effectiveness of the developed model for the preparation of pedagogical university students for organizing upbringing practices.

\section{CONCLUSION}

The results of the theoretical study, as well as the practical experience of our group of authors, support the importance of the problem of preparing teachers to organize upbringing 
practices. It is established that the process of practice-oriented training of pedagogical university students is effective under the condition of its specialized and purposeful organization. The developed model contributes to high-quality training of pedagogical students for goal-setting, design, implementation, and assessment of upbringing practices and allows developing the value attitude of teachers to performing the labor function of "Upbringing activity".

The materials presented in the article can be practically useful in the process of organizing the educational process of pedagogical universities in the context of implementing the operational programs of upbringing.

Authors' Contributions: Gorshenina, S. N.: conception and design, acquisition of data, analysis and interpretation of data, drafting the article, critical review of important intellectual content. Buyanova, I. B.: conception and design, acquisition of data, analysis and interpretation of data, drafting the article, critical review of important intellectual content. Neyasova, I. A.: conception and design, acquisition of data, analysis and interpretation of data, drafting the article, critical review of important intellectual content. Serikova, L. A.: conception and design, acquisition of data, analysis and interpretation of data, drafting the article, critical review of important intellectual content. Shukshina, T. I.: conception and design, acquisition of data, analysis and interpretation of data, drafting the article, critical review of important intellectual content. All authors have read and approved the final version of the manuscript.

Ethics Approval: Not applicable.

Acknowledgments: The research was carried out within the framework of the grant for research work on the priority areas of scientific activities of the partner networking universities (I.Ya. Yakovlev Chuvash State Pedagogical University and Moscow City University) on the topic "Scientific and methodical support for the preparation of future teachers for upbringing activities".

\section{REFERENCES}

Andreev, V. I. (2013). Pedagogika vysshei shkoly. Innovatsionno-prognosticheskii kurs: Uchebnoe posobie [Pedagogy of higher school. Innovative and prognostic course: Textbook]. Kazan: Tsentr innovatsionnykh tekhnologii, $500 \mathrm{p}$.

Baiborodova, L. V., Gruzdev, M. V., \& Kharisova, I. G. (2018). Podgotovka budushchikh pedagogov k vospitatelnoi deiatelnosti [Preparation of future teachers for upbringing activities]. Yaroslavl Pedagogical Bulletin, 2, 17-25. https://doi.org/10.24411/1813-145X-2018-10002

Belova, T. A., Vardanyan, Y. V., Chumanina, R. D., Kondratyeva, N. P., Kudashkina, O. V., \& Savinova, T. V. (2018). Developmental peculiarities of value and life-purpose orientations in the structure of psychological culture in adolescence. Modern Journal of Language Teaching Methods, 8(9), 388-395.

Belyaeva, N. F., Volkova, M. S., Miroshkin, V. V., Shepeleva, E. V., \& Yakuncheva, M. G. (2018). Using folk pedagogy teaching potential in patriotic and ethnocultural education of pedagogical institute students. Modern Journal of Language Teaching Methods, 8(12), 369-376.

Black, P., Harrison, C., Lee, C., Marshall, B., \& William D. (2003). Assessment for learning. Putting it into practice. Berkshire: Open University Press, 135 p.

Buyanova, I. B., Gorshenina, S. N., Neyasova, I. A., Serikova, L. A., \& Shukshina, T. I. (2020). Training a specialist in the field of upbringing for designing an individual route. Ad Alta: Journal of Interdisciplinary Research, 10(1(S11)), 59-62.

Chikova, O. A., Shakhnovich, I. S., \& Popp, I. A. (2021). Otsenka effektivnosti konkursnykh vospitatelnykh meropriiatii: analiz opyta ispolzovaniia metodologii modelirovaniia strukturnymi uravneniiami [Assessing the effectiveness of contest upbringing: an analysis of the experience of using structural equation modeling methodology]. Perspectives of Science and Education, 4(52), 448-460. https://doi.org/10.32744/pse.2021.4.30

Demakova, I. D., \& Shustova, I. lu. (2018). Pedagog kak vospitatel: Znachimye kharakteristiki vospitatelnoi deiatelnosti, printsip so-bytiinosti v vospitanii [Pedagogue as an educator: Significant characteristics of upbringing activity, the principle of co-existence in education]. Pedagogicheskoe iskusstvo, 2, 32-41.

Fiofanova, O. A. (2012). Psikhologiia vzrosleniia i vospitatelnye praktiki novogo pokoleniia: Uchebnoe posobie [Psychology of growing up and upbringing practices for the new generation: Textbook]. Moscow: FLINTA: NonGovernmental Educational Institution of Higher Vocational Education "Moscow Psychological and Social Institute", $120 \mathrm{p}$. 
Goodyear, P., Salmon, G., Spector, M., Steeples, C., \& Tickner, S. (2001). Competencies for online teaching: A special report. Educational Technology Research \& Development, 49(1), 65-72. https://doi.org/10.1007/BF02504508

Gorshenina, S. N., Buianova, I. B., Neiasova, I. A., \& Serikova, L. A. (2020). Praktiko-orientirovannaia podgotovka budushchikh pedagogov k realizatsii vospitatelnykh tekhnologii [Practice-oriented training of future teachers for the implementation of upbringing technologies]. Global Scientific Potential, 12(117), 139-141.

Gorshenina, S. N., \& Neiasova, I. A. (2018). Keis-zadacha kak sredstvo praktiko-orientirovannoi podgotovki budushchego pedagoga $\mathrm{k}$ vospitatelnoi deiatelnosti klassnogo rukovoditelia [Case-task as a means of practice-oriented preparation of a future teacher for the upbringing activity of a class teacher]. The Humanities and Education, 9(3(35)), 39-45.

Ilanlou, M., \& Zand, M. (2011). Professional competencies of teachers and the qualitative evaluation. Procedia - Social and Behavioral Sciences, 29, 1143-1150. http://dx.doi.org/10.1016/j.sbspro.2011.11.348

Kraevskii, V. V., \& Lerner, I. la. (Ed.). (1983). Teoreticheskie osnovy soderzhaniia obshchego srednego obrazovaniia [Theoretical foundations of the content of general secondary education]. Moscow: Pedagogika, $352 \mathrm{p}$.

Kulebyakina, M. Yu., Ivanova, T. A., Kapkaeva, L. S., Derbedeneva, N. N., \& Pronkina, V. M. (2018). Implementation of the regional model of additional education of children in the context of integration of additional general and higher education. Ciencia e Tecnica Vitivinicola, 33(12), 108-116.

Kurteeva, O. V. (2021). Tekhnologiia formirovaniia gotovnosti budushchego pedagoga k konstruirovaniiu soderzhaniia vospitatelnogo proekta [Technology for the formation of future teacher's readiness to design the content of an upbringing project]. Perspectives of Science and Education, 2(50), 176-186. https://doi.org/10.32744/pse.2021.2.12

Kutnyak, S. V., Kizhaeva, D. V., Dementieva, E. V., \& Falileev, A. E. (2019). The new generation counselor: System and training technology. Dilemas Contemporaneos-Educacion Politica y Valores, 6(3), 51.

Milovanova, N. G., \& Faizullina, A. R. (Compl.). (2021). Uspeshnye vospitatelnye praktiki: Metodicheskie rekomendatsii dlia klassnykh rukovoditelei, zamestitelei direktorov po vospitatelnoi rabote, sovetnikov direktorov po vospitaniiu i rabote $s$ detskimi obedineniiami [Successful upbringing practices: Methodological recommendations for the class teachers, deputy principals on upbringing, advisors to the directors on upbringing and work with children's associations]. Tiumen: Tyumen Regional State Institute for the Development of Regional Education, 24 p.

Orlova, I. V. (2016). Trening professionalnogo samopoznaniia: Teoriia, diagnostika i praktika pedagogicheskoi refleksii [Training of professional self-knowledge: Theory, diagnostics, and practice of pedagogical reflection]. Saint Petersburg: Rech, $128 \mathrm{p}$.

Petty, G. (2006). Evidence-based teaching. A practical approach. Cheltenham: Nelson Thornes, 382 p.

Rean, A. A., Bordovskaia, N. V., \& Rozum, S. I. (2002). Psikhologiia i pedagogika [Psychology and pedagogy]. Saint Petersburg: Piter, $432 \mathrm{p}$.

Robinson, W. (2006). Teacher training in England and Wales: Past, present and future perspectives. Educational Research and Perspectives, 2(33), 19-36.

Selivanova, N. L., , Stepanov, P. V., Kruglov, V. V., Parfenova, I. S., Stepanova, I. V., Cherkashin, E. O., \& Shustova, I. Iu. (Compl.). (2020). Vospitanie+ Avtorskie programmy shkol Rossii (izbrannye moduli): Sbornik [Upbringing + Author's programs for Russian schools (selected modules): A collection]. Moscow: Federal State Budgetary Scientific Institution "Institute for Strategy of Education Development of the Russian Academy of Education", 97 p.

Shumeiko, A. A. (2017). Formirovanie individualnogo stilia deiatelnosti v sisteme pedagogicheskogo obrazovaniia: Monografiia [The formation of individual style of activity in the system of pedagogical education: Monograph]. Komsomolsk-on-Amur: Federal State Budgetary Educational Institution of Higher Education "Amur Humanitarian and Pedagogical State University", 270 p.

Shustova, I. Iu. (2021). Modelirovanie obrazovatelnoi situatsii v prostranstve so-bytiinosti [Modeling an educational situation in the space of co-existence]. Izvestiya of Saratov University. Educational Acmeology. Developmental Psychology, 10(1(37)), 4-11. https://doi.org/10.18500/2304-9790-2021-10-1-4-11

Wayne, A. J., \& Youngs, P. (2004). Teacher characteristics and student achievement gains: A review. Educational Research, 73(1), 89-122. http://dx.doi.org/10.3102/00346543073001089

Zeichner, K. M., \& Conklin, H. G. (2005). Teacher education programmes. In: Cochran-Smith, M., Zeicher, K. M. (Eds.). Studying teacher education: The report of the AERA panel on research and teacher education. Washington: AERA; Mahwah: Lawrence Erlbaum, pp. 645-735. 
Received: 30 July 2021 | Accepted: 22 November 2021 | Published: 31 January 2022

(c) (1)

This is an Open Access article distributed under the terms of the Creative Commons Attribution License, which permits unrestricted use, distribution, and reproduction in any medium, provided the original work is properly cited. 